\title{
Pengaruh Nutrisi Ab Mix Terhadap Pertumbuhan Tanaman Bayam Merah (Amaranthus tricolor L.) Secara Hidroponik
}

\author{
Lilik Hidayanti ${ }^{1}$, Trimin Kartika $^{* 2}$ \\ *e-mail: triminkartika1969@gmail.com \\ ${ }^{1,2}$ Program Studi Biologi Fakultas MIPA, Universitas PGRI Palembang
}

\begin{abstract}
This research is aimed to find out the effects of $\mathrm{AB}$ mix Nutrition on the Growth of Red Spinach (Amaranthus tricolor L.) in Hydroponics, from June 2019 to August 2019 in the Workshop of the Faculty of Mathematics and Natural Sciences, PGRI University, Palembang. The purpose of this study was to determine the effect of administering a dose of $\mathrm{AB}$ mix nutrition on the growth of red spinach (Amaranthus tricolor L.). The research method was an experiment in a Completely Randomized Design (CRD), using 5 treatments 4 replications namely P0 (control / no nutrition), P1 (5 ml AB mix nutrition), P2 (10 ml AB mix nutrition), P3 (15 ml AB nutrition mix), P4 (20 ml nutrient AB mix), analyzed by Analysis of Variance Analysis (ANSIRA). The parameters observed were plant height, number of leaves and wet weight. The results showed that the administration of $\mathrm{AB}$ mix nutrient dose significantly affected plant height, number of leaves and the wet weight of red spinach (Amaranthus tricolor L.). The best treatment of $\mathrm{P} 3$ at a dose of $15 \mathrm{ml}$ with plant height of $24.2 \mathrm{~cm}$, number of leaves 13.25 strands and plant wet weight of 18.825 grams, the lowest yield at P0 treatment with plant height of $5.65 \mathrm{~cm}$, number of leaves of 8.5 strands and plant wet weight of 0.375 gram.
\end{abstract}

Keywords: Hydroponics, AB mix, Growth, Amaranthus tricolor L.

\begin{abstract}
ABSTRAK
Penelitian ini bertujuan untuk mengetahui Pengaruh Nutrisi AB mix Terhadap Pertumbuhan Tanaman Bayam Merah (Amaranthus tricolor L.) secara Hidroponik, pada bulan Juni 2019 sampai Agustus 2019 di Workshop Fakultas MIPA Universitas PGRI Palembang. Tujuan dari penelitian ini adalah mengetahui pengaruh pemberian dosis nutrisi $\mathrm{AB}$ mix terhadap pertumbuhan tanaman bayam merah (Amaranthus tricolor L.). Metode penelitian adalah eksperimen dalam Rancangan Acak Lengkap (RAL), menggunakan 5 perlakuan 4 ulangan yaitu $\mathrm{P}_{0}$ (kontrol/tanpa nutrisi), $\mathrm{P}_{1}$ ( $5 \mathrm{ml}$ nutrisi $\mathrm{AB}$ mix $), \mathrm{P}_{2}(10 \mathrm{ml}$ nutrisi $\mathrm{AB}$ mix $), \mathrm{P}_{3}(15 \mathrm{ml}$ nutrisi $\mathrm{AB}$ mix $), \mathrm{P}_{4}(20 \mathrm{ml}$ nutrisi $\mathrm{AB}$ mix), dianalisis dengan Analisis Sidik Ragam (ANSIRA). Parameter yang diamati adalah tinggi tanaman, jumlah daun dan berat basah. Hasil penelitian menunjukkan bahwa pemberian dosis unsur hara $\mathrm{AB}$ mix berpengaruh nyata terhadap tinggi tanaman, jumlah daun dan berat basah tanaman bayam merah (Amaranthus tricolor L.). Perlakuan terbaik P3 dengan dosis $15 \mathrm{ml}$ dengan tinggi tanaman 24,2 $\mathrm{cm}$, jumlah daun 13,25 helai dan berat basah tanaman 18,825 gram, hasil terendah pada perlakuan P0 dengan tinggi tanaman $5.65 \mathrm{~cm}$, jumlah daun 8,5 helai dan berat basah tanaman 0,375 gram.
\end{abstract}

Kata Kunci: Hidroponik, AB mix, Pertumbuhan, Amaranthus tricolor L. 


\section{PENDAHULUAN}

Sayuran merupakan salah satu produk pertanian yang banyak dikonsumsi oleh masyarakat pedesaan maupun perkotaan. Sistem budidaya sayuran yang dilakukan masyarakat Indonesia umumnya secara konvensional, untuk memenuhi tingkat konsumsi sayuran nasional perlu diimbangi dengan peningkatan produksi sayuran yang berkualitas.Upaya peningkatan produktivitas dan kualitas sayuran secara konvensional telah banyak dilakukan oleh petani meskipun hasilnya kurang memuaskan. Hidroponik merupakan salah satu sistem budidaya pertanian yang digunakan untuk memperbaiki kualitas sayuran yang dihasilkan.

Tanaman bayam merupakan tanaman berbentuk perdu atau semak yang digemari oleh seluruh lapisan masyarakat Indonesia. Hal ini disebabkan karena selain rasanya enak dan lunak, bayam juga memberikan rasa dingin dalam perut dan dapat memperlancar pencernaan. Bayam memiliki kandungan vitamin $\mathrm{A}, \mathrm{B}$ dan $\mathrm{C}$, protein, lemak, karbohidrat kalium, amaratin, serta mineral-mineral yang penting seperti kalsium, fosfor dan besi yang bermanfaat dalam mendorong pertumbuhan dan menjaga kesehatan. Kandungan besi pada bayam relatif lebih tinggi dibanding sayuran daun lain sehingga tanaman ini sangat baik dikonsumsi oleh penderita anemia (Nurmas dan Fitriah,2011).

Saat ini perkembangan industri semakin maju dengan pesat. Perkembangan tersebut banyak yang menggeser lahan pertanian, lebih-lebih di daerah perkotaan. Akibatnya, lahan pertanian semakin sempit. Disisi lain kebutuhan akan hasil pertanian semakin meningkat seiring dengan meningkatnya jumlah penduduk. Oleh karena itu perlu dipikirkan jalan keluar untuk mengatasi kondisi tersebut. Hidroponik merupakan salah satu alternatif yang dapat digunakan untuk meningkatkan produktivitas tanaman, terutama pada lahan sempit (Harjoko, 2010).

$\begin{array}{ccr}\text { Salah satu budidaya tanaman } \\ \text { selain } & \text { konvensional, untuk }\end{array}$ meningkatkan kualitas sayuran bayam merah (Amaranthus tricolor L.) dapat menggunakan teknologi hidroponik secara sederhana. Sistem budidaya hidroponik merupakan budidaya tanaman tanpa menggunakan tanah sebagai media tanam dengan penambahan nutrisi hara untuk pertumbuhan (Herwibowo dan Budiana, 2014).

Aspek penting yang perlu juga diperhatikan dalam menentukan keberhasilan budidaya hidroponik adalah pengelolaan tanaman yang meliputi persiapan bahan media, larutan nutrisi, pemeliharaan, aplikasi larutan nutrisi, panen dan pasca panen. Pemberian nutrisi yang tepat pada sistem hidroponik akan memberikan hasil yang optimal bagi pertumbuhan tanaman bayam merah, selain itu pertumbuhan tanaman tidak lepas dari lingkungan tumbuhan terutama faktor media tanam yang secara langsung akan mempengaruhi hasil tanaman (Mas'ud,2009).

Tanaman bayam merah (Amaranthus tricolor L.) ditanam secara hidroponik dengan menggunakan metode floating hidroponik. Floating hidroponik merupakan metode yang dikembangkan pertama kali oleh Jensen (1980) di Arizona dan Massantini (1978) di Italia. Floating Hydroponic System (FHS) atau Sistem hidroponik rakit apung membuat akar tanaman secara terus menerus mendapatkan nutrisi dan hara mineral 
yang menyebabkan tanaman akan tumbuh dan berkembang dengan baik.

Nutrisi dalam hidroponik dibagi menjadi 2 yaitu nutrisi yang mengandung unsur makro dan yang mengandung unsur mikro. Nutrisi yang mengandung unsur makro yaitu nutrisi yang dibutuhkan dalam jumlah banyak seperti N, P, K, S, Ca, dan $\mathrm{Mg}$. Nutrisi yang mengandung unsur mikro merupakan nutrisi yang dibutuhkan dalam jumlah yang sedikit seperti $\mathrm{Mn}, \mathrm{Cu}$, $\mathrm{Zn}, \mathrm{Cl}, \mathrm{Cu}, \mathrm{Na}$ dan Fe. Nutrisi yang dipakai untuk tanaman bayam merah secara hidroponik adalah nutrisi $\mathrm{AB}$ mix. Nutrisi $A B$ mix terdiri dari pekatan $A$ dan pekatan B yang nantinya diencerkan dengan perbandingan 1:1000.

Menurut Nugraha (2014), AB mix merupakan larutan hara yang terdiri dari stok A yang berisi unsur hara makro dan stok B berisi unsur hara mikro. Menurut Jensen (2007) nutrisi yang biasa digunakan dalam teknik hidroponik adalah AB Mix. Permasalahan saat ini adalah nutrisi AB Mix sulit ditemui dan harganya mahal. Nutrisi yang dipakai untuk tanaman bayam merah secara hidroponik adalah nutrisi $\mathrm{AB}$ mix dengan pemberian dosis yang berbeda-beda untuk setiap perlakuannya.

Berdasarkan uraian diatas, perlu diteliti pengaruh nutrisi $\mathrm{AB}$ mix terhadap pertumbuhan tanaman bayam merah (Amaranthus tricolor L.) secara hidroponik dengan metode floating hydroponic. Penelitian ini bertujuan untuk:Mengetahui pengaruh pemberian nutrisi $\mathrm{AB}$ mix dengan dosis yang berbeda terhadap pertumbuhan tanaman bayam merah. Mengetahui dosis nutrisi AB mix yang dapat memberikan hasil terbaik terhadap pertumbuhan tanaman bayam merah.

\section{BAHAN DAN METODE}

Penelitian dilakukan pada bulan Juni 2019 sampai dengan Agustus 2019 bertempat di Workshop Fakultas MIPA Universitas PGRI Palembang. Data dianalisis di Laboratorium Biologi Terpadu Universitas PGRI Palembang. Adapun peralatan yang digunakan dalam penelitian ini adalah : Peralatan hidroponik seperti rockwool, tray penyemaian, cutter, pinset, cawan petri, botol plastik, cup plastik, wadah, semprotan, kertas label, styrofoam, suntikan dan alat tulis. Sedangkan bahan yang digunakan adalah : nutrisi $\mathrm{AB}$ mix dalam bentuk padat, benih bayam merah (Amaranthus tricolor L.), air.

Metode yang digunakan yaitu metode eksperimen dengan menggunakan Rancangan Acak Lengkap (RAL) yang terdiri dari 5 perlakuan dan 4 ulangan:

$\mathrm{P}_{0}$ : Kontrol tanpa nutrisi $\mathrm{AB}$ mix.

$\mathrm{P}_{1}: 5 \mathrm{ml}$ nutrisi $\mathrm{AB}$ mix/ liter air

$\mathrm{P}_{2}$ : $10 \mathrm{ml}$ nutrisi $\mathrm{AB}$ mix/ liter air

$\mathrm{P}_{3}: 15 \mathrm{ml}$ nutrisi $\mathrm{AB}$ mix/ liter air

$\mathrm{P}_{4}: 20 \mathrm{ml}$ nutrisi $\mathrm{AB}$ mix/ liter air

\section{HASIL DAN PEMBAHASAN}

\begin{tabular}{lcrr}
\multicolumn{1}{c}{ Hasil } & $\begin{array}{c}\text { analisis } \\
\text { bahwa }\end{array}$ & \multicolumn{2}{r}{ keragaman } \\
menerangkan & perlakuan \\
pemberian & nutrisi & $\mathrm{AB}$ & mix \\
berpengaruh & nyata & pada & tinggi \\
tanaman, jumlah daun, dan & berat \\
basah tanaman bayam & merah \\
(Amaranthus & tricolor & $\mathrm{L})$. & Hasil \\
analisis & keragaman & pengaruh \\
perlakuan pemberian nutrisi & $\mathrm{AB}$ mix
\end{tabular}


terhadap parameter yang diamati disajikan pada Tabel 1.

Tabel.1.Hasil analisis keragaman pengaruh perlakuan terhadap parameter yang diamati.

\begin{tabular}{cccc}
\hline Parameter & F.Hitung & \multicolumn{2}{c}{ F. Tabel } \\
\cline { 3 - 4 } yang diamati & & $\mathbf{5 \%}$ & $\mathbf{1 \%}$ \\
\hline Tinggi Tanaman & $7,08^{*}$ & 3,06 & 4,89 \\
Jumlah Daun & $3,75^{*}$ & & \\
Berat Basah & $3,18^{*}$ & & \\
\hline
\end{tabular}

Berdasarkan hasil Analisis Sidik Ragam terhadap parameter rata-rata tinggi tanaman, pemberian nutrisi $\mathrm{AB}$ mix pada tanaman bayam merah (Amaranthus tricolor L) berpengaruh sangat nyata. Dilanjutkan Uji Beda
Nyata Terkecil, hasil uji BNT terhadap parameter tinggi tanaman bayam merah akibat perlakuan pemberian dosis nutrisi $\mathrm{AB}$ mix yang berbeda disajikan pada tabel 2.

Tabel 2 Hasil uji BNT rata-rata tinggi tanaman bayam merah pada berbagai perlakuan pemberian dosis nutrisi $\mathrm{AB}$ mix.

\begin{tabular}{lc}
\hline \multicolumn{1}{c}{ Perlakuan } & $\begin{array}{c}\text { Rata-rata Tinggi Tanaman } \\
\text { Bayam Merah } \mathbf{( c m})\end{array}$ \\
\hline $\mathrm{P}_{0}($ kontrol/tanpa nutrisi) & $5,65 \mathrm{a}$ \\
$\mathrm{P}_{1}(5 \mathrm{ml}$ nutrisi $\mathrm{AB} \mathrm{mix} /$ liter air & $16,67 \mathrm{~b}$ \\
$\mathrm{P}_{2}(10 \mathrm{ml}$ nutrisi $\mathrm{AB} \mathrm{mix} /$ liter air & $20,67 \mathrm{~b}$ \\
$\mathrm{P}_{3}(15 \mathrm{ml}$ nutrisi $\mathrm{AB} \mathrm{mix} /$ liter air & $24,2 \mathrm{~b}$ \\
$\mathrm{P}_{4}(20 \mathrm{ml}$ nutrisi $\mathrm{AB} \mathrm{mix} /$ liter air & $20,5 \mathrm{~b}$ \\
\hline \multicolumn{1}{c}{ BNT $^{\mathbf{( 0 , 0 5}} \mathbf{: 8 , 1 0}$} &
\end{tabular}

Keterangan: Angka yang diikuti oleh huruf yang sama pada umur pengamatan yang sama menunjukkan berbeda nyata berdasarkan uji BNT 5\%.

Berdasarkan Tabel Analisis Sidik Ragam terhadap parameter jumlah daun, pemberian nutrisi $\mathrm{AB}$ mix pada tanaman bayam merah (Amaranthus tricolor L) memberikan hasil berpengaruh nyata.
Dilanjutkan Uji Beda Nyata Terkecil, hasil uji BNT terhadap parameter jumlah daun tanaman akibat perlakuan beda dosis nutrisi disajikan pada Tabel 3.

Tabel 3. Hasil Uji BNT rata-rata jumlah daun tanaman bayam merah pada perlakuan pemberian dosis nutrisi $\mathrm{AB}$ mix.

\begin{tabular}{lc}
\hline \multicolumn{1}{c}{ Perlakuan } & $\begin{array}{c}\text { Rata-rata Jumlah Daun } \\
\text { Bayam Merah } \mathbf{( c m})\end{array}$ \\
\hline $\mathrm{P}_{0}($ kontrol/tanpa nutrisi) & $8,5 \mathrm{a}$ \\
$\mathrm{P}_{1}(5 \mathrm{ml}$ nutrisi $\mathrm{AB}$ mix/ liter air & $12 \mathrm{~b}$ \\
$\mathrm{P}_{2}(10 \mathrm{ml}$ nutrisi $\mathrm{AB} \mathrm{mix} /$ liter air & $12,75 \mathrm{~b}$ \\
$\mathrm{P}_{3}(15 \mathrm{ml}$ nutrisi $\mathrm{AB} \mathrm{mix} /$ liter air & $13,25 \mathrm{~b}$ \\
$\mathrm{P}_{4}(20 \mathrm{ml}$ nutrisi $\mathrm{AB} \mathrm{mix} /$ liter air & $12,75 \mathrm{~b}$ \\
\hline \multicolumn{1}{c|}{ BNT $^{(\mathbf{0 , 0 5})} \mathbf{: 2 , 9 9}$} &
\end{tabular}

Keterangan: Angka yang diikuti oleh huruf yang sama pada umur pengamatan yang sama menunjukkan berbeda nyata berdasarkan uji BNT 5\%. 
Berdasarkan tabel Analisis Sidik Ragam terhadap parameter berat basah tanaman menunjukan perlakuan pemberian nutrisi $\mathrm{AB}$ mix pada tanaman bayam merah memberikan hasil yang berpengaruh nyata, dilanjutkan Uji Beda Nyata Terkecil (BNT). Hasil uji BNT terhadap parameter berat basah tanaman bayam merah disajikan pada Tabel 4 .

Tabel .4 Hasil Analisis Sidik Ragam rata-rata berat basah tanaman bayam merah pada berbagai perlakuan pemberian dosis nutrisi $\mathrm{AB}$ mix.

\begin{tabular}{lc}
\hline \multicolumn{1}{c}{ Perlakuan } & $\begin{array}{c}\text { Rata-rata Berat Basah } \\
\text { Tanaman Bayam Merah (gr) }\end{array}$ \\
\hline $\mathrm{P}_{0}$ (kontrol/tanpa nutrisi) & $0,375 \mathrm{a}$ \\
$\mathrm{P}_{1}$ (5 ml nutrisi AB mix/ liter air & $9,575 \mathrm{ab}$ \\
$\mathrm{P}_{2}(10 \mathrm{ml}$ nutrisi AB mix/ liter air & $12,025 \mathrm{~b}$ \\
$\mathrm{P}_{3}$ (15 ml nutrisi AB mix/ liter air & $18,825 \mathrm{~b}$ \\
$\mathrm{P}_{4}(20 \mathrm{ml}$ nutrisi AB mix/ liter air & $12,525 \mathrm{~b}$ \\
\hline
\end{tabular}

$\frac{\text { BNT }^{(\mathbf{0 , 0 5})}: \mathbf{1 1 , 3 0}}{\text { Keterangan: Angka yang diikuti oleh huruf yang sama pada umur pengamatan }}$
yang sama menunjukkan tidak berbeda nyata berdasarkan uji
BNT taraf 5\%

Pada Tabel 1 di atas hasil uji BNT taraf $5 \%$ dapat dilihat bahwa tanaman bayam merah memberikan respon yang berbeda nyata terhadap dosis nutrisi $\mathrm{AB}$ mix yang diberikan. Berdasarkan penelitian yang telah dilakukan, diperoleh hasil data statistik perhitungan total rata-rata tinggi tanaman bayam merah mengalami peningkatan pada perlakuan $\mathrm{P}_{1}$ (5 ml nutrisi $\mathrm{AB}$ mix) dengan rata-rata $18,675 \mathrm{~cm}$, lalu meningkat hingga perlakuan $\mathrm{P}_{3}(10$ $\mathrm{ml}$ nutrisi $\mathrm{AB}$ mix) dengan rata-rata 24,2 $\mathrm{cm}$ berarti dosis pada perlakuan $\mathrm{P}_{1}, \mathrm{P}_{2}, \mathrm{P}_{3}$ berbeda nyata dengan perlakuan $\mathrm{P}_{0}$. Pada perlakuan dosis $\mathrm{P}_{4}$ (20 ml nutrisi $\mathrm{AB}$ mix) memberikan hasil berbeda tidak nyata, dimana pertumbuhan mengalami penurunan dengan rata-rata sebesar $20,5 \mathrm{~cm}$.

Hasil rata-rata tinggi tanaman bayam merah tertinggi terdapat pada perlakuan $\mathrm{P}_{3}(15 \mathrm{ml}$ nutrisi $\mathrm{AB}$ mix/liter air) dengan rata-rata tinggi tanaman sebesar $24,2 \mathrm{~cm}$, sedangkan rata-rata tinggi tanaman terendah terdapat pada perlakuan $\quad \mathrm{P}_{0}$ (kontrol/tanpa nutrisi) dengan rata-rata tinggi tanaman sebesar $5,65 \mathrm{~cm}$. Dapat dilihat pada grafik 1 .

Tinggi tanaman bayam merah

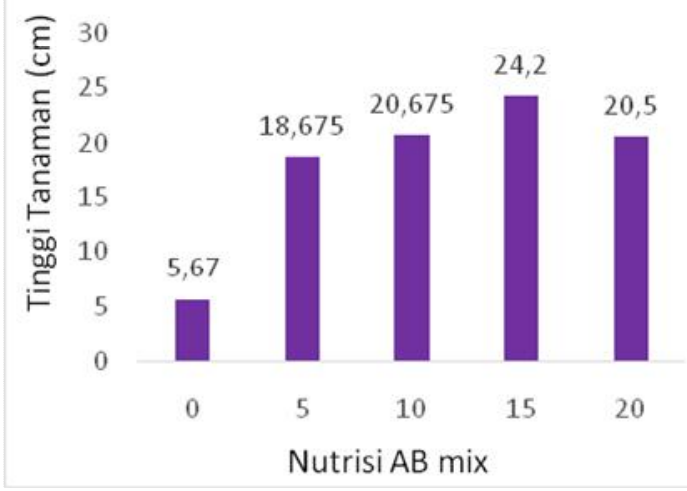

Grafik 1. Tinggi Tanaman Bayam Merah.

Pertumbuhan tinggi tanaman kurang memberikan hasil pada $\mathrm{P}_{0}$ diduga karena pada perlakuan (kontrol/tanpa nutrisi), air sebagai media pertumbuhan tanaman tidak memiliki cukup kandungan nutrisi yang berperan sangat penting dalam 
pertumbuhan tanaman. Sedangkan pada dosis $\mathrm{P}_{4}(20 \mathrm{ml}$ nutrisi $\mathrm{AB}$ mix $)$ pertumbuhan mengalami penurunan, menurunnya pertumbuhan tanaman diduga karena dosis nutrisi yang diberikan terlalu tinggi, sehingga tidak berfungsi memacu pertumbuhan tanaman, tetapi menyebabkan pertumbuhan tanaman menjadi terhambat. Hal ini sesuai dengan pernyataan Lawalata (2011), yang mengungkapkan bahwa pemberian unsur hara dapat meningkatkan pertumbuhan tanaman dalam jumlah yang sesuai kebutuhan tanaman. Jika terlalu berlebihan akan menyebabkan pertumbuhan menjadi terhambat.

Semua hara yang terkandung pada nutrisi hidroponik adalah unsur esensial yang diperlukan tanaman dalam pertumbuhan dan perkembangannya. Apabila unsur hara makro dan mikro tidak lengkap ketersediaannya, dapat menghambat pertumbuhan dan perkembangan tanaman (Pairunan, 2012).

Pola pertumbuhan tanaman umumnya membentuk kurva sigmoid. Periode awal dengan laju pertumbuhan eksponensial yang pendek, kemudian linier diikuti oleh fase yang lajunya menurun. Kurva signoid merupakan kurva pertumbuhan pada vase vegetatif sampai titik tertentu akibat pertumbuhan sel tanaman dan kemudian melambat (Gardner et al, 2012).

Pada Tabel 2 diatas hasil uji BNT taraf $5 \%$ dapat dilihat bahwa tanaman bayam merah memberikan respon yang berbeda terhadap dosis nutrisi hidroponik yang diberikan. Berdasarkan penelitian yang telah dilakukan, diperoleh hasil data statistik perhitungan jumlah daun mengalami peningkatan pada perlakuan $\mathrm{P}_{1}$ (5 ml nutrisi $\mathrm{AB}$ mix) dengan rata-rata 12 helai, lalu meningkat hingga perlakuan $\mathrm{P}_{3}(15 \mathrm{ml}$ nutrisi $\mathrm{AB}$ mix $)$ dengan rata-rata 13,25 helai, berarti dosis pada perlakuan $\mathrm{P}_{1}, \mathrm{P}_{2}, \mathrm{P}_{3}$ berbeda nyata dengan perlakuan $\mathrm{P}_{0}$. Pada perlakuan dosis $\mathrm{P}_{4} \quad(20 \mathrm{ml}$ nutrisi $\mathrm{AB} \quad \mathrm{mix})$ memberikan hasil berbeda tidak nyata pada perlakuan $\mathrm{P}_{1}, \mathrm{P}_{2}, \mathrm{P}_{3}$, dimana jumlah daun mengalami penurunan dengan ratarata 12,75 helai. Hasil jumlah daun tanaman bayam merah tertinggi terdapat pada perlakuan $\mathrm{P}_{3}$ dengan jumlah daun sebanyak 13,25 helai, sedangkan jumlah daun terendah terdapat pada perlakuan $\mathrm{P}_{0}$ dengan jumlah daun sebanyak 8,5 helai. Secara statistik terjadi kenaikan dan penurunan jumlah daun pada tanaman. Adanya perbedaan jumlah daun tanaman karena adanya respon tanaman yang berbeda terhadap pemberian dosis nutrisi. Dapat dilihat pada grafik 2.

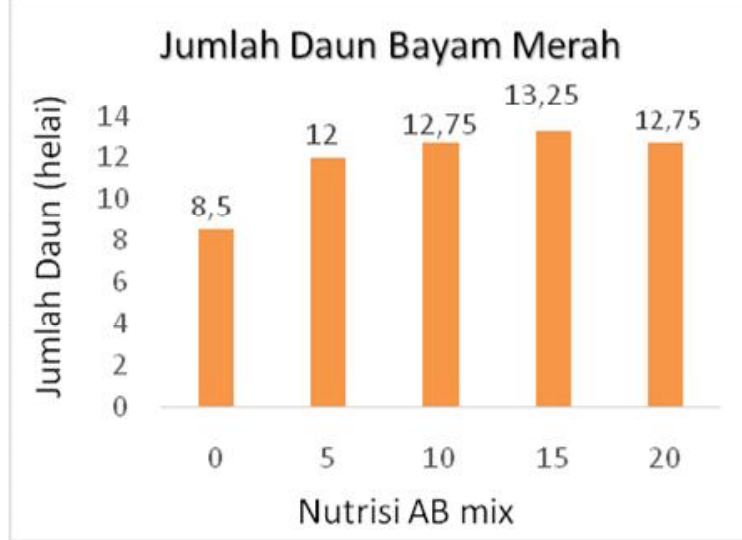

Grafik 2. Jumlah Daun Tanaman Bayam Merah

Berdasarkan hasil penelitian yang telah dilakukan diketahui bahwa semakin tinggi dosis nutrisi $\mathrm{AB}$ mix yang diberikan pada tanaman bayam merah maka semakin tinggi pertumbuhan tanaman dan semakin banyak jumlah daun pada tanaman bayam merah. Namun bila dosis nutrisi melewati batas dari kebutuhan 
tanaman hidroponik maka tanaman akan menunjukkan penurunan. Menurut Mas'ud (2009) larutan yang ada pada media harus kaya akan unsur hara untuk pertumbuhan tanaman sedangkan ketersediaan hara yang rendah akan menghambat proses fisiologi tanaman. Pemberian nutrisi dalam kadar tinggi beresiko membakar tanaman hidroponik.

Apabila nutrisi yang diberikan diatas ambang fitotoksisitas daun tanaman akan menjadi coklat. Daun yang coklat disebabkan oleh sel-sel yang mengalami plasmolisis karea air yang seharusnya masuk kedalam sel keluar dari daun. Penyebabnya adalah air sudah diserap oleh cairan hipertonis (lebih pekat) yang berada diluar sel dibandingkan dengan cairan hipotonis (lebih encer) yang berada didalam sel. Akibatnya sel kehilangan air dan sitoplasmanya terlepas dari dinding sel dan rusak yang disusul dengan kematian sel (Nurrohman, 2015).

Bagian sistem hidroponik yang harus jadi perhatian dalam mengembangkan sistem hidroponik antara lain :, kelembapan dan suhu, intensitas cahaya, elevasi (ketinggian tempat), serta derajat keasaman $(\mathrm{pH})$.

Pada Tabel 4 diatas hasil uji BNT taraf $5 \%$ pada berat basah bayam merah dapat dilihat bahwa tanaman bayam merah memberikan respon yang berbeda terhadap dosis nutrisi $\mathrm{AB}$ mix yang diberikan. Berdasarkan penelitian yang telah dilakukan, diperoleh hasil data statistik perhitungan jumlah berat basah tanaman mengalami peningkatan pada perlakuan $\mathrm{P}_{1}(5 \mathrm{ml}$ nutrisi $\mathrm{AB}$ mix) dengan rata-rata sebesar 9,575 gr, meningkat lagi pada perlakuan $\mathrm{P}_{3}(15 \mathrm{ml}$ nutrisi $\mathrm{AB}$ mix $)$ dengan rata-rata sebesar 18,825 gr. Perlakuan $\mathrm{P}_{1}$ dan $\mathrm{P}_{3}$ berpengaruh nyata dengan perlakuan $\mathrm{P}_{0}$ (Kontrol/tanpa perlakuan). Pada perlakuan dosis $\mathrm{P}_{4}(20 \mathrm{ml}$ nutrisi $\mathrm{AB}$ mix) memberikan hasil berbeda tidak nyata pada $\mathrm{P}_{1}$ (5 ml nutrisi $\mathrm{AB}$ mix), $\mathrm{P}_{2}$ ( $10 \mathrm{ml}$ nutrisi $\mathrm{AB}$ mix/liter air), $\mathrm{P}_{3}$ ( $15 \mathrm{ml}$ nutrisi AB mix/liter air).

Hasil berat basah tanaman bayam merah (Amaranthus tricolor L.) nilai tertinggi terdapat pada perlakuan $\mathrm{P}_{3}$ dengan berat basah sebesar 18,825 gr, sedangkan berat basah tanaman bayam merah (Amaranthus tricolor L.) nilai terendah terdapat pada perlakuan $\mathrm{P}_{0}$ (Kontrol/tanpa perlakuan) dengan berat basah sebesar 0,375 gr. Berat basah tanaman bayam merah (Amaranthus tricolor L.) dapat dilihat pada grafik 3 .

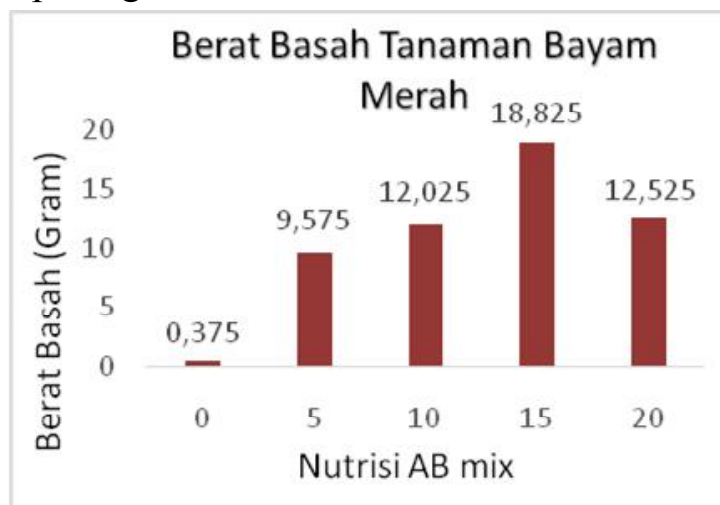

Grafik 3. Berat Basah Tanaman Bayam Merah.

Pertumbuhan berat basah tidak memberikan hasil pada $\mathrm{P}_{0}$ diduga karena pada perlakuan (kontrol/tanpa nutrisi). Air sebagai media pertumbuhan tanaman tidak cukup memiliki kandungan nutrisi yang 
berperan sangat penting dalam pertumbuhan tanaman, sedangkan pada dosis P4 $(12,52)$ pertumbuhan tanaman bayam merah mengalami penurunan, menurunnya pertumbuhan tanaman bayam diduga karena dosis nutrisi yang diberikan terlalu tinggi akibatnya nutrisi tersebut tidak berfungsi untuk memacu pertumbuhan tanaman tetapi menyebabkan pertumbuhan tanaman menjadi terhambat.

$\begin{array}{rrr}\text { Berat } & \text { basah merupakan } \\ \text { variabel } & \text { untuk mengukur }\end{array}$ pertumbuhan tanaman. Laju pertumbuhan tanaman dapat diukur dengan berbagai cara salah satu cara ialah dengan mengukur pertumbuhan dalam berat segar atau berat basah total. Cara ini dapat dilakukan selama tumbuhan dalam keadaan segar dan sedang tumbuh (Campbell and Reece, 2008).

Perbedaan berat basah tanaman karena respon pemberian dosis nutrisi yang berbeda terhadap pertumbuhan tanaman . Pemberian perbedaan dosis nutrisi pada pertumbuhan tanaman bayam merah memberikan pengaruh nyata terhadap parameter pengamatan. Hal ini sejalan dengan penelitian Perwtasari (2012) serta Nurrohman (2015), yang juga mendapatkan pengaruh yang nyata terhadap pertumbuhan berat basah, tinggi tanaman dan jumlah daun total Lactuca sativa dan Brassica juncea $\mathrm{L}$.

Nutrisi $\mathrm{AB}$ mix mengandung unsur hara makro $(\mathrm{N}, \mathrm{P}, \mathrm{K}, \mathrm{Mg}, \mathrm{Ca}$, $\mathrm{S}, \mathrm{C}, \mathrm{H}$ dan $\mathrm{O}$ ) dan unsur hara mikro ( $\mathrm{B}, \mathrm{Cu}, \mathrm{Fe}, \mathrm{Mn}, \mathrm{Zn}, \mathrm{Mo}$ ). Unsur hara makro diserap tanaman dalam jumlah yang banyak dan unsur hara mikro diperlukan dalam jumlah sedikit tetapi harus ada. Kebanyakan unsur hara mikro berfungsi sebagai penyusun enzim dan vitamin sedangkan untuk unsur hara makro berfungsi untuk merangsang pertumbuhan, mensintesa asam amino dan protein, merangsang pertumbuhan akar dan biji, merangsang pembelahan sel tanaman, memperkuat batang tubuh tanaman dan meningkatkan daya tahan tanaman terhadap penyakit (Winda, 2013).

\section{KESIMPULAN}

Berdasarkan hasil penelitian yang telah dilakukan maka dapat disimpulkan sebagai berikut :

1. Pemberian dosis nutrisi $\mathrm{AB}$ mix berpengaruh nyata terhadap tinggi tanaman bayam merah, jumlah daun dan berat basah bayam merah.

2. Pada $\mathrm{P}_{3}$ dengan dosis $15 \mathrm{ml}$ nutrisi $\mathrm{AB}$ mix menunjukkan hasil tertinggi terhadap parameter tinggi tanaman sebesar $24,2 \mathrm{~cm}$, jumlah daun sebesar 13,25 helai dan berat basah tanaman bayam merah sebesar 18,825 gram, hasil terendah pada $\mathrm{P}_{0}$ (Kontrol/tanpa nutrisi $\mathrm{AB}$ mix) menunjukkan hasil terhadap tinggi tanaman sebesar 5,65 cm, jumlah daun sebesar 8,5 helai dan berat basah sebesar 0,375 gram.

\section{DAFTAR PUSTAKA}

Campbell, N. A., dan J. B. Reece. (2008). Biologi Edisi ke 8 Jilid 1 . (diterjemahkan dari : Biology Eighth Edition, penerjemah : D.T. 
Wulandari). Penerbit Erlangga. Jakarta.

Direktorat Jendral Hortikultura. (2009). Statistik Produksi Hortikultura tahun 2005-2008. Kementrian Pertanian, Jakarta.

Gardner, P.F., R.B. Pearce and R.L Mitohell. (1991). Fisiologi Tumbuhan Budidaya. UI Press. Jakarta.

Herwibowo, K., dan N.S. Budiana. (2014). Hidrponik Sayuran. Penerbit Penebar Swadaya. Jakarta.

Jensen, M.H. (2007). Hydroponics worldwide. ISHS Acta Horticulturae 481 pp.719-730.,In International Symposium on Growing Media and Hydroponics, Journal Hort Technology 2(98).

Kratky, B.A. (2009). A Capillary, Noncirculating Hydroponic Method for Leaf and Semi-head Lettuce. Journal Hort Technology. 3(2).

Lawalata, J. (2011). Pemberian Kombinasi ZPT terhadap Regenerasi Gloxinia Secara In vitro. Journal Exp Life Sci. Vol 1 No. 2. Fakultas Pertanian Universitas Pattimura. Ambon.

Lingga, P. (2002). Hidroponik: Bercocok Tanam Tanpa Tanah. Edisi, revisi. Penebar Swadaya. Jakarta.

Mas'ud, H. (2009). Sistem Hidroponik Dengan Nutrisi dan Media Tanam Berbeda Terhadap Pertumbuhan dan Hasil Selada. Media Litbang Sulteng 2(2).

Nugraha, R. U., (2014). Sumber Hara Sebagai Pengganti AB mix Pada Budidaya Sayuran Daun Secara Hidroponik. Dalam Aris S., Evie R. Dan Herlina F. Fermentasi Limbah Cair Tahu Menggunakan EM4 Sebagai Alternatif Nutrisi Hidroponik dan Aplikasinya pada Sawi Hijau (Brassica juncea var.tosakan). Laboratorium Sumberdaya Lahan Universitas Pembangunan Nasional Surabaya.

Nurmas, A., dan S.P. Fitriah. (2011). Pengaruh Jenis Pupuk Daun dan Jenis Mulsa Terhadap Pertumbuhan dan Produksi Bayam Merah (Amaranthus tricolor L.). Jurnal Agroteknos Vol.1 No.2.

Nurrohman, M. (2015). Pengaruh Pemberian Dosis Nutrisi AB mix Terhadap Tanaman Sawi (Brassica juncea L) Secara Hidroponik. Jurnal Protan Vol 2. No.8.

Pairunan et al,. (2013). Dasar-dasar Ilmu Tanah. Badan Kerja Sama P.T.N Indonesia Timur, jung Pandang.

Perwtasari, B. (2012). Pengaruh Media Tanam dan Nutrisi Terhadap Tanaman Pakcoy ( Brassica juncea) Secara Hidroponik. Jurnal Agrovigar Vol.5 No.1 Universitas Trunjoyo Madura.

Harjoko D, dan Samanhudi. (2010). Pengaturan Komposisi Nutrisi dan Media Dalam Budidaya Tanaman 
Tomat Dengan Sistem Hidroponik.

Biofarm Jurnal Ilmiah Pertanian.

Vol. 13. No. 9. 2010. UNS.

Surakarta.

Winda, Y. (2013). Dinamika Unsur Hara Makro di Dalam Tanah dan Tanaman. Rineka Cipta. Jakarta. 